\title{
犬の慢性関節りウマチに対する関節固定術の応用
}

\author{
堅木道夫，多川政弘，梅田昌樹，織間博光， \\ 熟巣 誠, 江島博康，本好茂一
}

\section{Arthrodesis in a Dog with Rheumatoid Arthritis}

\author{
Michio KATAGI, Masahiro TAGAWA, Masaki UMEDA, \\ Hiromitsu ORIMA, Makoto WASHIZU, Hiroyasu EJIMA and Shigekatsu MOTOYOSHI
}

\begin{abstract}
A 6-year-old female maltese showed a walk with its weight bearing on the intercarpal joints of both forelegs since approximately 50 days ago. This was soon followed by the wobbling of the bilateral hindlegs.

Plain X-ray examination to the four legs revealed remarkable resorption of bones bilaterally in the elbow joints, intercarpal joints, stifle joints and tarsal joints. Antinuclear antibody reaction test and rheumatoid factor in this case were both negative. However, since the clinical condition of this dog satisfied seven of the eleven diagnostic criteria specified by the American Rheumatism Association, the diagnosis of rheumatoid arthritis was established. The initial treatments consisted of administration of steroid and aspirin. Arthrodesis of the both carpal and stifle joints was performed and the result was satisfactory. Also the local irradiation of low-energy laser beam might stop the pain in this patient.
\end{abstract}

Key words : $\operatorname{dog}$ (犬), arthrodesis (関節固定術), rheumatoid arthritis (慢性関節りウマチ), laser(レーザー).

\section{は じゆに}

慢性関節りウマチ（RA）は，両側性に糜爛，浸 食を来たす多発性関節炎で，その病態は関節組織 内に対する免疫複合体の沈着によって介在される 自己免疫疾患である。RA の発生は，ヒトのみな らず犬に扔いて認められ，その病態，治療法など について英国，米国を中心に報告1-3,7,11,12)されて いる。

RA の臨床症状は, 初期段階で関節滑膜に炎症

日本獣医畜産大学（干180 武蔵野市境南町 1-7-1)

Nippon Veterinary and Zootechnical College, 1-

7-1 Kyonanchyo, Musashino, Tokyo 180, Japan.
が起こり，多発性または対称性に関節を浸すこと によって進行する。すなわち，骨萎縮や軟骨およ び骨の糜爛と破壊が進行し，支持する靶帯も損傷 し，その結果から亜脱臼，脱臼あるいは強直を来 たして著しい運動機能障害を引き起こす。これら 関節に起こる変化は，ヒトおよび犬で近似してい るが，相違点としてヒトでは関節以外の全身症状 を示すケースが多いが犬では発熱以外の全身症状 が認められないために診断上，困難を来たしてい る $^{1-3,11)}$ 。

今回著者らは，多発性に関節軟骨の破壊と骨吸 収を呈した犬の症例に遭遇し, 臨床症状および種 
々の検植所見から RA と診断したのでその概要を 報告与子

\section{症例}

症例は,マルチーズ, 雌, 6 歳, 体重 $2.2 \mathrm{~kg}$ である。产訴は，5 力月程前から雨側前肢の手根 関節部で負重して歩行するよらになり，さらに3 カ月前から画側後肢に跛行を垫めるようになっ た。その時点で獣医陑の治療を受けたが改善せ ず，症状がますます恶化したためにその原因究明 上治療劣目的之し, 日本獣医畜産大学付属家畜病 院へ来院した。

既応症は, 子犬の時期にケンネルコフに罹患し， 2 歳の時後肢を打撲して一時跛行を呈したことが あった。ジステンハー, 伝染性肝炎, ハルボウイ ルス感染症に対するワクチン接種を毎年1 回ずつ 行ってきた。

初診時の一般臨床所見において, 体温 $38.0^{\circ} \mathrm{C}$ で若干削瘦はしているものの元父，食欲は良好で， 排便，排尿にも買常は認められなかった。犬は，

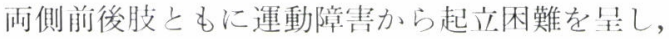
触骖によって曲肢の関節は可動時に疼痛が認めら れた。手根関節は腫脹して外力へ属曲し，その部 分に結節状の硬結部が認められた。

\section{レントゲン検査所見}

臨床症状の最も著しい手根関節の単純レントゲ ン所見に沶いて，手根骨は完全に消失し，橈骨遠 位端抒よび中手骨近位端にも著しい骨吸収像が認 められた（Fig. 1 および 2)。股関節部に抋いて， 大腿骨周辺の軟部組織に結節状の石灰沈着が認め られた。また両側の膝関節は腫脹しており，変位 が認められることから靶带断裂が疑われるととも に関節に近接する大腿骨および頸骨が廃用性萎縮 と思われる骨の粗铥化を示㖫するX線透過性の京 進が認められた（Fig. 3)。その他，胸部の単純レ ントゲン所見で軽度の父管虚脱を羿めた。

\section{血液検査所見}

初診時吴施した血液検査所見は, Table 1 に亦 すよらに AST, ALT おょび ALP が高值を示

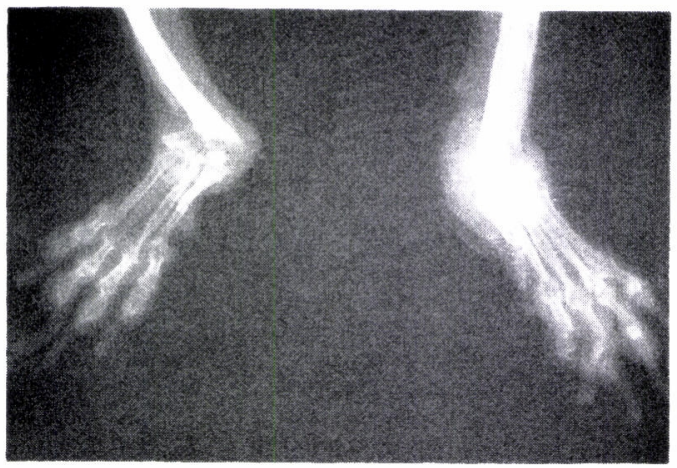

Fig. 1 An anterio-posterier radiograph of the forelegs at first admission.

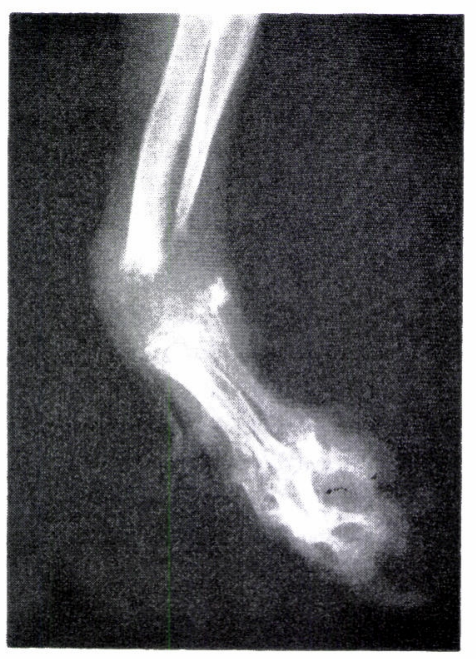

Fig. 2 A left lateral radiograph at the same time. The bones of the radiocarpal joint and the proximal phalangeal joint were widely destructed.

し，肝機能障害を示唆する所見が得られた以外， 特記所見は認められなかった。また，リウマチ因 子打よび抗核抗体は陰性であった。

\section{関節滑液の検査所見}

手根関節部の穿刺吸引によって採取した関節滑 液について検查を行った。滑液は, 外観上無色透 明で粘稠性に火けていた。滑液涂淋のギムザ染色 標本では, 単球および好中球が認められ, 慢性の 炎症像を示唆する所見が得られた。滑液の細菌学 的検查の結果は陰性で, 細菌の存在は認められな 


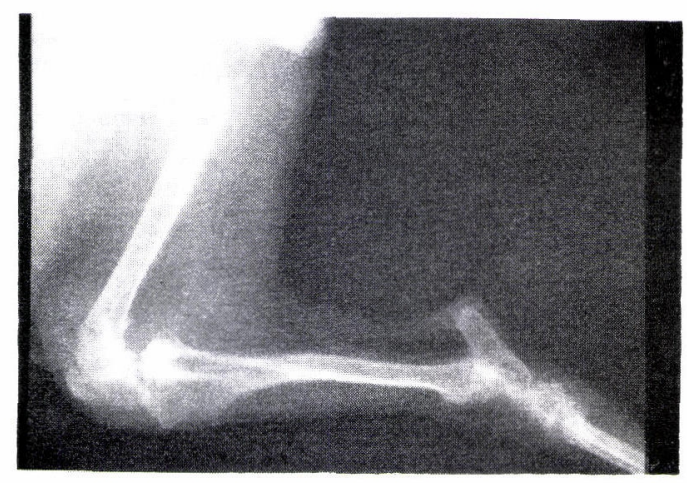

Fig. 3 A lateral radiograph of the stifle joint, in which the ligaments might be ruptured probably because of the arthritis.

Table 1 Results of the blood examination

\begin{tabular}{lll}
\hline RBC & $593 \times 10^{4}$ & $/ \mu l$ \\
Ht & 42 & $\%$ \\
WBC & 13,100 & $/ \mu l$ \\
TP & 7.8 & $\mathrm{~g} / \mathrm{dl}$ \\
AST & 54 & $\mathrm{IU}$ \\
ALT & 269 & $\mathrm{IU}$ \\
ALP & 897 & $\mathrm{IU}$ \\
BUN & 18.9 & $\mathrm{mg} / \mathrm{dl}$ \\
Creatinine & 0.9 & $\mathrm{ing} / \mathrm{dl}$ \\
\hline
\end{tabular}

かった。

\section{臨床経過および治療方法}

本症例を前䛉のような臨床症状および検查所見 からアメリカ・リウマチ協会の診断悬淮にもとず き RA と䛦断14)して治療を試及た。李ず，関 節局所の疼痛緩和と消炎を目的でアスヒりン 5 $\mathrm{mg} / \mathrm{kg}$ × 1 日 2 回， 7 月間経口投与したが，骨 破壊が著しいためか臨术症状は改善さ九なか。 た。そこで，最も骨破壊が著しい手根関䬣汇おい て橈骨执よび中手骨の骨端が皮膚穿孔する伦除 性があったため，併せてその部分の機能改善を画 るために雨側の手根関節の润定術を実施した。す

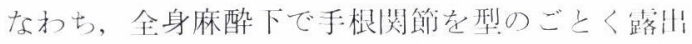
し，橈骨之中手骨の間の軟骨お卡び関節包堂除去 したのち，T字型骨接命用フレートで固定した。 その際，両骨間の癒合を促進する月的でハイドロ

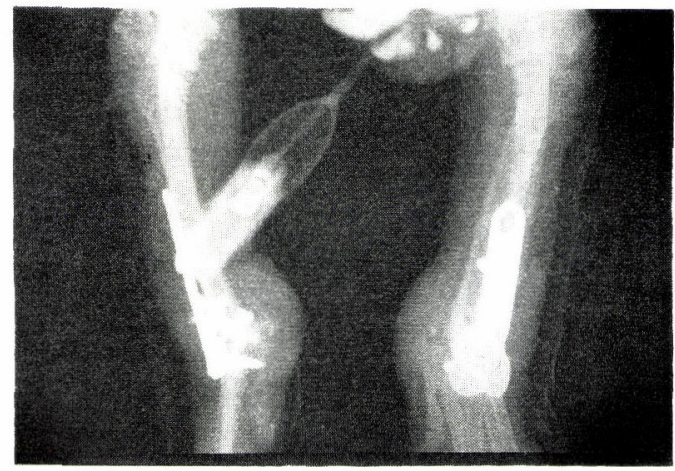

Fig. 4 A radiograph of both intercarpal joints after the arthrodesis.

キシアパタイト（アパ七ラム顆粒；アサヒ光学社） 老充慎した (Fig. 4)。術後は, アスピリン $10 \mathrm{mg} /$ $\mathrm{kg}$ を 1 月 2 回，30日間経口投与し，そののちフ レドニゾロン $5 \mathrm{mg} /$ 頭を 1 日 1 回，30 日間経口 投与したが臨床症状の改善は認めらなかったため 投薬を中心:した。

手根関節の沽定術の結果は良好で, 両側前肢と もに負重可能になった。その時点で機能障害を起 こしている膝関節に対して骨接合用プレートによ 万固定術を实施した。その後は, 約 1 力月間経過 を観察したが，犬は痛又のためか夜間睡服できな いと飼主から訴光があったため, 疼痛緩和と消炎 を目的に低エネルギーの半導体レーザー装置（才 サダ・ダイオトロン)を使用して各関節に対して 30 $\mathrm{mW}, 60 \sim 120$ 秒の条件で 1 日 2 3 回連日照射 したところ犬は照射後睡眠できるようになった。

\section{病理組織学的所見}

関節固定術実施の際に切除した膝関節部分の骨 摽木について病理組織学的検查を行った。その結 果, いずれも関節軟骨が消失し，その表面はパン 又スと呼壮れる線維性肉芽組織で被われ，䄉毛の 増生も垫められた（Fig. 5 捻よび 6)。史た，血 管に富んだ結命組織の増生之若干のリンバ球，形 質細胞の没潤も㴓められた。

\section{考察}

慢性関節りウマチは，人医面に求いて世界人口 の） $2 \%$ 以上に影響孝与えている難治性の不具性 


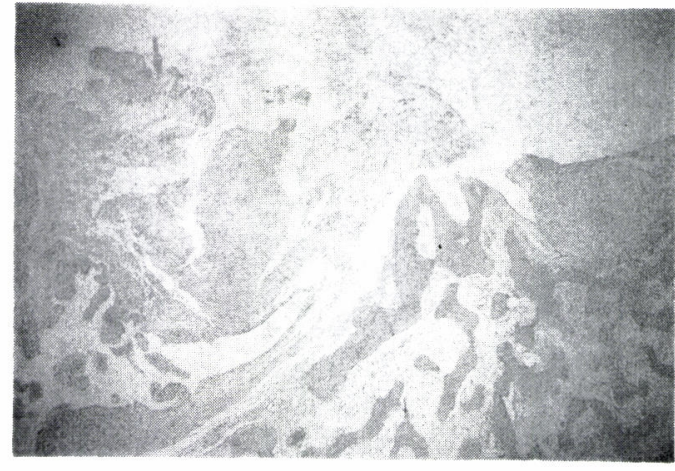

Fig. 5 The bone specimen obtained by the arthrodesis of the stifle joint. The articular cartilage disappeared and is covered with fibrous granulation tissue. There is proliferation of villi at the lower left. (HE stain)

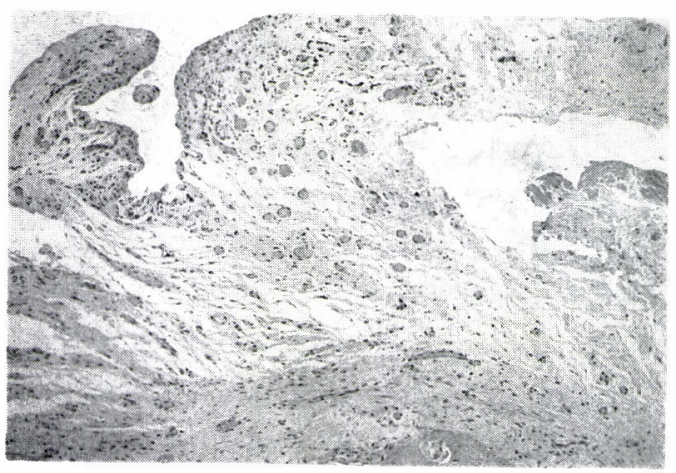

Fig. 6 The same specimen as Fig. 5. Fibrous granulation tissue (pannus) seems to extend as if to cover the articular surface. The lesion is enriched with connective tissue fibers and blood vessels, and is infiltrated by some lymphocytes and plasmocytes. Fibrins are attached on both the left and right sides. (HE stain)

の関節疾患で，その障害は関節のみならず心, 肺, 神経，筋など全身性に抢よぶものである $8,10,13$ 。 犬の RA に関する報告は，諸外国では認められ るものの木邦に拉いては皆無に等しい。

自己免疫疾患である $\mathrm{RA}$ の診断は，人医面に おいても定型的な関節の变形やレントゲン所見, 血清中のリウマチ因子陽性などの所見が認められ たものに対して診断は容易であるが，初期病変や
定型的な症状を示さない症例に対しては困難であ る。そこでヒトでは Table 2 に示すアメリカ・ リウマチ協会の診断基準 ${ }^{14)}$ が適用されている ${ }^{2,3)}$ 。 獣医面でも諸外国に拈いてその診断基準が適用さ れ，犬の血清りウマチ因子の測定法も開発され臨 床応用されている1”。しかし，本邦ではいまだと RA の診断法が確立されていないのが現状であ る。

今回報告した症例の診断は, 獣医面において諸 外国の研究者 $1,3,7)$ が行っている方法と同じくアメ リカ・リウマチ協会の診断基準を採用して行った。 その結果, 本症例は表中の(1)安静後のこわばり,(2) 少なくとも 1 関節以上の疼痛, (3)関節の軟部組織 の腫脹, (5)対称性の関節腫脹, (6)皮下結節の存在, (7)RA の定型的なレントゲン像，(10)関節滑膜の定 型的な病理組織像, と 11 項目中 7 項目を満たし ていることから RA と診断した。

現在，犬の RAの治療は，人医面之同様に初期 病変に対しては抗炎症剂, 免疫抑制剂を中心とし た薬物療法が行なわれる ${ }^{3,7,9)}$ 。本症例のように進 行したRAに対しては薬物療法は効果が期待でき ないために関節滑膜の切除，人工関節置換術など の手術療法が通常は適用される。本症例でも当初 アスピリンとプレドニゾロンを使用したが，関節 病変の進行は阻止できなかったため, 運動機能の 改善を期待して関節固定術を実施した結果, ある 程度満足できる成績が得られた。このことから， 関節病変が進行し重度な運動機能不全に拈ちいっ ている症例に対して関節固定術が対症療法として 有用であると思われる。

近年, 人医面に打いて RAの治療に半導体や一 リウムネオンをエネルギー源とした低出力レーザ 一が応用され，矢の有效性が報告 ${ }^{4,5,6)}$ されてい る。すなわち, その作用として, 肉芽組織の症痕 化の促進, 免疫系への関与, 関節滑膜の線維化お よびリンパ球浸潤の抑制などの他に疼痛緩和が挙 将らている。事実，本症例に対して半導体レー ザーを連日照射することによって犬は痛みを訴兄 なくなり，夜間睡眠できるよらになったもので， 本装置の有用性が示唆された。

今後は，本邦に执いてRAの診断基準の確立と 
Table 2 Criteria for the diagnosis of rheumatoid arthritis* by American Rheumatism Association

\section{Criteria :}

1. Morning stiffness.

2. Pain on motion at least one joint.

3. Soft tissue joint swelling.

4. Soft tissue swelling of at least one other joint within 3 months.

5. Symmetrical joint swelling.

6. Subcutaneous nodules over bony prominences.

7. Appropriate radiographic changes.

8. Serological evidence of rheumatoid factor.

9. Poor mucin precipitate following addition of acetic acid.

10. Characteristic histopathological examination of synovial membrane.

11. Characteristic histological changes in nodules.

\section{Exclusions :}

1. Dermatological signs of SLE or high concentrations of LE cells (four or more in two smears).

2. Evidence of infective arthritis.

3. Evidence of hypertrophic asteoarthropathy.

Diagnosis :

1. Classic RA-7 or more criteria satisfied $\dagger$.

2. Definite RA-5 or more criteria satisfied.

3. Probable RA-3 or more criteria satisfied.

4. Possible RA-2 criteria satisfied.

† Criteria 1 to 5 must be present for at least 6 weeks ( 3 weeks in the case of possible RA).

リウマチ因子の測定の開発が望まれる。

\section{結語}

年秢 6 歳の雌のマルチーズが 5 カ月程前から両 側の手根関節で負重しながら歩行するよらにな り，その後，両側後肢にふらつきを認めるように なったとのことで上診した。

四肢の単純レトンゲン検査によって両側の肘関 節，手根関節，膝関節掞よび足根関節に掞いて顕 著な骨吸収像が認められた。抗核抗体は陰性であ り，リウマチ因子も陰性であったが，アメリカ・ リウマチ協会の診断基準 11 項目中 7 項目を満た していることから慢性関節リウマチと診断した。 また採取した関節部分の組織所見の結果，特徵的 なパンヌス panusを認めた。犬は，ステロイド 剂，アスピリンの投与および関節固定術に加え， 低エネルギーレーザー照射による局所療法を行っ

た結果，経過は良好である。

参考 文 献

1) Bennet, D. (1987) : Immune-based erosive inflammatory joint disease of the dog: canine rheumatoid arthritis. 1. Clinical, radiological and laboratory in. vestigations. J. Small Anim. Pract. $28: 779-797$.

2) Biery, D.N., and Newton, C.D. (1975): Radiographic appearance of rheumatoid arthritis in the dog. J. Am. Anim. Hosp. Assoc. $11: 607-612$.

3) Halliwell, R.E.W., and Gorman, N.T. (1989) : Veterinary Clinical Immunology, pp. 337-358. W.B. Sounders, Philadelphia. 
4) 井上康二, 西岡淳一, 福田眞輔（1988）： 低出カレーザー照射が慢性炎症に及ぼす影 響. 日本レーザー医学会誌 $9: 69-71$.

5）小幡純一，柳瀬昌㢱，木村明江，坂牧玲子 （1987）：漫性関節リウマチにおける低出力 レーザーの鎮痛効果. ペインクリニック $8: 18-22$.

6) 小幡純一, 柳瀬昌弘, 高橋信夫, 本村明江, 鵜原令子 (1988)：慢性関節リウマチの低出 カレーザー療法による骨, 関節病変の長期 乳後, 日本レーザー医学会誌 $9: 73-76$.

7) Lewis, R.M. and Picut, C.A. (1989) : Veterinary Clinical Immunology; from Classroom to Clinics., pp. 148-166. Lea \& Febiger, Philadelphia.

8) 行山 康, 廣瀬俊一(1978)：リウマチ性疾 患の免疫学. 臨床免疫学の進歩第 $5, \mathrm{pp}$. 63-83. 近代出版社, 東京.

9) Newton, C.D., Lipowitz, A.J., Halliwell, R.E.W., Allen, H.I., Biery, D.N., and Schumacher, H.R. (1976) : Rheumatoid arthritis in dogs. J. Am. Vet. Med.
Assoc. 113-121.

10）野島孝之，松野丈夫（1990）：慢性関節リウ マチ, 病理と臨床 $8: 302-305$.

11) Pedersen, N.C., Pool, R.C., Castles, J.J., and Weisner, K. (1976) : Non-infectious canine arthritis; Rheumatoid arthritis. J. Am. Vet. Med. Assoc. 169 : 295303.

12) Pedersen, N.C., Pool, R.C., and Obrien, T. (1980) : Feline chronic progressive polyarthritis. Am. J. Vet. Res. 41 : 522-535.

13) Robinson, D.R., Tashjia, A.H., and Levine, L. (1975) : Prostaglandin-stimulated bone resorption by rheumatoid synovia. A possible mechanism for bone destruction in rheumatoid arthritis. J. Clin. Invest. $56: 1181-1188$.

14) Ropes, M.W. (1959) : Diagnostic criteria for rheumatoid arthritis; 1958 revision. Annals of the Rheumatic Diseases. 18 : 49-53. 